PaWet NoWAK

Uniwersytet Pedagogiczny w Krakowie, Polska - Pedagogical University of Cracow, Poland

\title{
Ochrona konsumenta przez ustawowe limitowanie opłat kredytowych
}

\section{Consumer Protection through Statutory Debt Limits}

Streszczenie: Przedmiotem artykułu jest przedstawienie i ocena obecnie obowiązujących limitów ustawowych, mających na celu ograniczenie odsetkowych i pozaodsetkowych kosztów kredytów konsumenckich na tle ewolucji podejścia do wynagrodzenia od kapitału (lichwy). Zostały poruszone w nim religijne, etyczne, prawne i ekonomiczne argumenty dotyczące lichwy. Z przeprowadzonej analizy wynika, że w warunkach wysokiego zróżnicowania instytucjonalnego sektora kredytowo-pożyczkowego w Polsce wpływ limitów opłat ma zróżnicowany i wielowymiarowy charakter. Ocenę odziaływania regulacji można formułować w aspekcie wyzysku, nadmiernego zadłużenia, wykluczenia finansowego i ogólnego dobrobytu społecznego. Poczynione wnioski wskazują, iż ustawowe ograniczenia kosztów kredytów konsumenckich wywołują pod wieloma względami negatywne skutki uboczne. Powodują m.in. ograniczenie dostępu najsłabszym konsumentom do kredytów niskokwotowych na krótki okres i rozwój szarej strefy. Dlatego mimo szlachetnych przesłanek ustawodawcy skuteczniejsze w obniżaniu ceny kredytu i poprawie ogólnego dobrobytu jest wspieranie przez państwo podażowej strony rynku przez ograniczanie ryzyka prowadzenia działalności gospodarczej i rozwój konkurencji. Artykuł powstał na podstawie studiów literatury przedmiotu oraz analizy przepisów prawnych, regulujących maksymalny poziom odsetkowych i pozaodsetkowych kosztów kredytów konsumenckich.

Abstract: The subject of the article is presenting the assessment of currently applicable statutory limits, aimed at limiting the interest and non-interest costs of consumer loans against the background of the evolution of the approach to remuneration from capital (usury). Religious, ethical, legal and economic arguments about usury were raised. The analysis shows that in the conditions of high institutional differentiation of the credit-loan sector in Poland, the impact of fees limits is diverse and multidimensional. Evaluation of the impact of regulation can be formulated in the aspect of exploitation, excessive debt, financial exclusion and general social well-being. The conclusions indicate that the statutory limitations of consumer credit costs have negative side effects in many respects. They cause, among others, the limiting of access to short-term low-value loans for the weakest consumers and the development of the gray market. Therefore, despite the noble premises of the legislator, it is more effective to reduce the price of credit and improve the general well-being by supporting the supply side of the market by limiting the risk of running a business and developing competition. The article was based on the study of the subject literature and the analysis of legal provisions regarding the maximum interest and non-interest costs of consumer loans. 
Słowa kluczowe: bezpieczeństwo konsumenta; koszty kredytu; lichwa; ochrona konsumenta

Key words: consumer protection; consumer safety; loan costs; usury

Otrzymano: 18 listopada 2018

Receieved: 18 November 2018

Zaakceptowano: 23 lutego 2019

Accepted: 23 February 2019

\section{Sugerowana cytacja/Suggested citation:}

Nowak, P. (2019). Ochrona konsumenta przez ustawowe limitowanie opłat kredytowych. Przedsiębiorczość - Edukacja [Entrepreneurship - Education], 15(1), 230-241. doi: 10.24917/20833296.151.16

\section{Wstęp}

Rozwój rynku pożyczkowo-kredytowego jest obecnie w Polsce bardzo dynamiczny. Rośnie średnia kwota zaciąganych kredytów (pożyczek), jak również wydłuża się okres kredytowania. Dynamicznemu rozwojowi rynku towarzyszy wzrost zaległych zobowiązań płatniczych, co świadczy o rosnących problemach kredytobiorców z obsługą zobowiązań (InfoDług..., 2018). Jest to sygnał ostrzegawczy, który może wskazywać, że zdolność spłaty zobowiązań nie nadąża za rozwojem rynku.

Ochrona interesów zadłużonych ma cel indywidualny i zbiorowy. Realizowana jest za pomocą różnych narzędzi regulacyjnych, do których należą m.in. ustawowe limity kosztów kredytu. Jej bezpośrednim celem jest ochrona kredytobiorców przed lichwą (ponoszeniem nadmiernych opłat), która może prowadzić do problemów ze spłatą kredytu lub wpędzać kredytobiorców w spiralę zadłużenia. Kłopoty finansowe zadłużonych często mają dla nich katastrofalne skutki osobiste, ale również w warunkach masowego charakteru tego zjawiska tworzą ryzyko systemowe i stanowią zagrożenie ogólne.

Artykuł prezentuje ewolucję podejścia do wynagrodzenia od kapitału (lichwy) w ujęciu historycznym. Zawiera omówienie aktualnych przepisów prawa limitujących odsetkowe i pozaodsetkowe koszty kredytu konsumenckiego oraz wskazuje na konsekwencje wprowadzonych rozwiązań. Zastosowano w nim metodę analizy opisowej i krytycznej.

\section{Ochrona przed lichwą - rys historyczny}

Termin „lichwa” używany jest w szerokim i wąskim znaczeniu. Towarzyszą temu skojarzenia negatywne, łączące je $\mathrm{z}$ wyzyskiem dłużnika. W szerokim znaczeniu w pojęciu tym mieści się każde wynagrodzenie za pożyczkę pieniężną lub niepieniężną, natomiast w wąskim zakresie jest to wynagrodzenie w wygórowanej wysokości, pobierane $\mathrm{z}$ wykorzystaniem przymusowej sytuacji dłużnika. Współcześnie pod pojęciem lichwy rozumie się najczęściej odsetki od pożyczonego kapitału w wygórowanej wysokości.

Najstarsze istniejące zapiski regulujące kwestię odsetek pochodzą z XVII w. p.n.e. i znajdują się w Kodeksie Hammurabiego. Kodeks przewidywał maksymalne odsetki w wysokości $20 \%$ dla pożyczek udzielonych w gotówce i $331 \frac{1}{3} \%$ w przypadku pożyczek zbożowych (Bień, A., Bień, W., 2009: 141). Również prawo rzymskie przewidywało dwunastoprocentowy limit odsetek.

Stosunek do lichwy kształtowany był i jest przez religie. Główne religie były przeciwne lichwie, ponieważ pożyczanie pieniędzy kończyło się często ruiną dłużników i czyniło 
z nich niewolników. Konsekwencje niespłacenia długu były tragiczne. Niewypłacalny dłużnik popadał w nędzę i stawał się własnością wierzyciela, który mógł go sprzedać wraz z całą rodziną (Krajewski, 2018). Przez wieki lichwa była traktowana jako grzech ciężki i była potępiana przez główne religie monoteistyczne: chrześcijaństwo, judaizm i islam.

Stosunek do wynagrodzenia od kapitału był przez wieki negatywny. Arystoteles uważał, że pieniądz nie powinien być pożyczany na procent, ponieważ jest to sprzeczne z jego naturą. Wyraził to w następujący sposób: „z najzupełniejszą słusznością znienawidzone jest rzemiosło lichwiarza, ponieważ w tym przypadku osiąga zysk z samego pieniądza, który mija się ze swoim przeznaczeniem. Stworzony bowiem został dla celów wymiany, a tymczasem przez pobieranie procentów sam się pomnaża [...]. Toteż ten sposób zarobkowania jest w największym stopniu przeciwny naturze" (Arystoteles, 1953: 24).

Negatywny stosunek do odsetek istniał przez kolejne wieki średniowiecza. Wielki autorytet tamtego okresu, św. Tomasz z Akwinu, uważał, że pieniądz jest „bezpłodny” i nie może rodzić wartości. Pełni funkcję środka wymiany, a pobieranie odsetek jest grzechem ciężkim jako wykroczenie przeciwko przykazaniu „nie kradnij”. Z czasem zakaz pobierania odsetek ulegał stopniowemu „rozszczelnieniu” i pojawiały się od niego kolejne wyjątki. Od XIII w. dopuszczalne było pobieranie odsetek od pożyczek zaciąganych przez władców, jeżeli nie dotrzymywali terminów ich spłaty. Wierzyciel mógł inkasować przedmiot zastawu lub odsetki od kwot nieuregulowanych w terminie. Tak powstał majątek Zakonu Ubogich Rycerzy Chrystusa Świątyni Salomona (Templariuszy), który doprowadził ostatecznie do ich zguby. Król Francji Filip IV Piękny pozbył się długu wobec zakonu, dokonując konfiskaty majątku i spalenia zakonników na stosie pod zarzutem herezji. W średniowieczu pojawiały się również, innowacyjne jak na owe czasy, sposoby obchodzenia zakazu pożyczania pieniędzy, np. przez przekazanie gotówki w zamian za rentę (prawo do korzystania z ziemi dłużnika). Wierzyciel nie otrzymywał odsetek tylko ziemię a dłużnik zobowiązywał się do odkupienia ziemi w późniejszym terminie. Papież Innocenty IV w XIII w. akceptował kontrakt dożywotniej renty, nawet jeżeli łączny dochód pożyczkodawcy był wyższy od kwoty pożyczki.

Kościół katolicki surowo potępiał pobieranie odsetek, a pożyczanie na procent traktował jako grzech śmiertelny. Oficjalne stanowisko w tej sprawie zajął w dekrecie w $1187 \mathrm{r}$. papież Urban III - za lichwę uznał każde wynagrodzenie od udzielonej pożyczki, uznając, że pożyczka powinna służyć jedynie jako bezpłatna pomoc bliźniemu znajdującemu się w potrzebie (Bień, A., Bień, W., 2009: 142).

Wyłomem w zakazie pobierania jakiegokolwiek wynagrodzenia od pożyczonego kapitału stały się banki pobożne (montes pietatis) utworzone przez franciszkanów w XV w. Franciszkanin Bernardyn ze Sieny sformułował tezę, że istnieją dwa rodzaje lichwy: rzeczywista i pozorna. Lichwa pozorna występuje wtedy, gdy oprocentowanie pożyczek jest niskie, natomiast lichwa rzeczywista, gdy jest ono wysokie. Banki pobożne powstały, aby stworzyć ubogim dostęp do tanich pożyczek (oprocentowanych w wysokości 5-10\% rocznie) i tym sposobem chronić ich przed lichwą rzeczywistą. Ostatecznie w 1917 r. ogłoszony przez papieża Benedykta XV Kodeks prawa kanonicznego pozwolił pożyczkodawcom na pobieranie zadośćuczynienia w formie legalnego zysku (Krajewski, 2018).

Koran i prawo szariatu zakazują zupełnie do dnia dzisiejszego pobierania odsetek. Jako pierwsi sposób pozwalający ominąć zakaz wymyślili w VIII w. hanafici, posługując się podwójną sprzedażą. Polega ona na sprzedaży rzeczy przez osobę potrzebującą pożyczki ze zobowiązaniem odkupienia jej w późniejszym czasie po wyższej cenie, w którą 
wliczone zostało wynagrodzenie od pożyczonego kapitału. W 2005 r. we wszystkich regionach świata, gdzie występowały większe skupiska muzułmanów, funkcjonowało ponad 300 banków islamskich oferujących produkty finansowe odpowiadające zasadom określonym w Koranie i prawie szariatu (Gostomski, 2018). Koncepcja funkcjonowania banków zgodnie z prawem szariatu, tzn. bez transakcji lichwiarskich oraz m.in. z zakazem finansowania przemysłu tytoniowego, spirytusowego, produkcji wieprzowiny, powstała w połowie XIX w., a za pierwszy bank islamski na świecie uważa się utworzone w $1963 \mathrm{r}$. w Mit Ghamr Egipskie Towarzystwo Oszczędnościowe, które w latach 70. XX w. połączyło się z Nasser Social Bank. Banki islamskie oferują produkty finansowe o charakterze udziałowym, które obciążone są wyższym ryzkiem dla banku. W przypadku produktów tego typu banki nie pobierają odsetek, ale uczestniczą w podziale zysków lub ponoszeniu strat.

Tora zezwalała na pożyczanie innowiercom, ale wielu Żydów płaciło wysoką cenę w postaci pogardy i prześladowań za uprawianie grzesznego zawodu. Pożyczanie współbraciom było zakazane. Judaizm nakazywał nawet co siedem lat, przy okazji roku szabatowego, umarzać długi współbraciom niemogącym spłacić kredytów. Żydzi pozbawieni prawa do posiadania ziemi i wykonywania pewnych zawodów coraz szerzej z prawa pożyczania korzystali. W ten sposób powstały wielkie rody bankierskie Rothschildów czy Rockefellerów.

Religia wywarła wpływ na rozwój gospodarczy obszarów świata znajdujących się pod jej wpływem. Akceptacja lichwy przez judaizm, a w końcu i chrześcijaństwo, przyczyniła się do rozwoju gospodarczego krajów Zachodu i tłumaczy, dlaczego w tej części świata powstał kapitalizm. Brak akceptacji odsetek od kapitału uznawany jest jako jedna z przyczyn zacofania krajów islamskich (Ratajczak, 2012: 288-289). Ocena wpływu religii na zjawiska gospodarcze jest złożona - trzymanie się konserwatywnych reguł koranicznych jest oceniane również pozytywnie jako czynnik, który ochronił banki islamskie przed kryzysem finansowym 2008-2010 (Aqahtani, Mayes, 2018).

Stosunek do wynagrodzenia od pożyczonego kapitału oparty był na stosunku do pieniądza. W okresie, w którym uważano, że pieniądz jest bezproduktywny i ma służyć jedynie jako środek wymiany, negatywnie patrzono na odsetki. Kiedy zmieniło się podejście do pieniądza, zmieniło się również spojrzenie na odsetki. Zaczęto akceptować i regulować zasady ich pobierania.

Rozwój handlu z krajami zamorskimi w XV w. wzmógł potrzebę pożyczania i zapoczątkował zmianę podejścia do odsetek. Zaczął dominować pogląd, że słuszne jest, aby pożyczkodawca dzielił się korzyściami, jakie osiąga z pożyczonego kapitału. Od momentu, w którym uznano, że odsetki są uczciwym wynagrodzeniem za kapitał, dzięki któremu można pomnażać bogactwo, pożyczanie pieniędzy przestało być zajęciem hańbiącym i pogardzanym, a bankierzy zaczęli cieszyć się szacunkiem (Galbraith, 1991: 23). Zakaz pobierania odsetek wraz z rozwojem wymiany i gospodarki kapitalistycznej był stopniowo rozluźniany (Thurow, Heibroner, 2006: 14-19). Ekonomia klasyczna nadała znaczenie środkom pieniężnym jako zasobowi, dzięki któremu możliwe jest pomnażanie bogactwa.

\section{Aktualne regulacje lichwy}

W Polsce w czasie zaborów istniały regulacje antylichwiarskie na terenie każdego zaboru. W zaborze austriackim obowiązywały najbardziej ogólne zapisy dotyczące lichwy. 
Zabraniały one czerpania nadmiernych korzyści przez pożyczkodawców - takich, które mogły wywołać ruinę ekonomiczną dłużnika, a których pożyczkobiorca nie był w stanie zrozumieć ze względu na słabość rozumu, niedoświadczenie lub wzruszenie (Korzeb, 2017: 128). Karze podlegał nie tylko wierzyciel pierwotny, ale także wtórny. Karą za lichwę był areszt i grzywna.

W zaborze pruskim karze podlegała osoba wykorzystująca potrzebę, niedoświadczenie, lekkomyślność; osiągająca odsetki przekraczające zwykłą stopę odsetkową, pozostającą w rażącej dysproporcji w stosunku do wyświadczonej usługi.

W zaborze rosyjskim zakaz lichwy regulował Kodeks karny, w którym była mowa o nadmiernym procencie, którego winnym jest osoba, wykorzystująca trudną sytuację pożyczkobiorcy na warunkach skrajnie dla niego uciążliwych. Artykuł 608 określał, iż „pożyczanie kapitału na procent, nie przynoszący dwunastu od sta rocznie nie jest karygodne" (Korzeb, 2017: 129). W ten sposób nadmierne odsetki zostały wyraźnie uregulowane w rosyjskim kodeksie karnym. Postać lichwy mogły mieć również kary umowne wtedy, gdy miały charakter uciążliwy i rujnujący.

W okresie międzywojennym ukazało się Rozporządzenie Prezydenta RP o lichwie pieniężnej z dnia 29 czerwca 1924 r. Zgodnie z art. 1 tego rozporządzenia nie wolno było pobierać korzyści majątkowych w jakiejkolwiek formie w wysokości przewyższającej 24\% od sta rocznie w gotówce lub innej wartości. Umowy, w których korzyść majątkowa była wyższa, stawały się z mocy prawa nieważne. Kodeks karny kwalifikował lichwę jako przestępstwo przeciwko mieniu. Warunkiem istnienia lichwy było wyzyskanie przymusowego położenia i niewspółmierność świadczeń (ich krzywdzący charakter). Lichwa mogła występować przy wszystkich czynnościach prawnych.

Uchwalony w 1964 r. Kodeks cywilny uchylił całkowicie prawo o lichwie z 1924 r. (Dz.U. 2018, poz. 1025 t.j.). Artykuł $388 \$ 1$ k.c. stanowi, że „Jeżeli jedna ze stron, wyzyskując przymusowe położenie, niedołęstwo lub niedoświadczenie drugiej strony, w zamian za swoje świadczenie przyjmuje albo zastrzega dla siebie lub dla osoby trzeciej świadczenie, którego wartość w chwili zawarcia umowy przewyższa w rażącym stopniu wartość jej własnego świadczenia, druga strona może żądać zmniejszenia swego świadczenia lub zwiększenia należnego jej świadczenia, a w wypadku gdy jedno i drugie byłoby nadmiernie utrudnione, może ona żądać unieważnienia umowy”. Jedną z przyczyn dość ograniczonego znaczenia przepisu art. 388 dla praktyki obrotu cywilnoprawnego są trudności dowodowe, co do świadomości wyzyskującego, iż zawierając umowę wiedział o niekorzystnej sytuacji kontrahenta (przymusowym położeniu, niedołęstwie lub niedoświadczeniu). Wyzyskany może żądać zmniejszenia jego świadczenia lub zwiększenia należnego mu świadczenia, a w wypadku, gdy jedno i drugie byłoby nadmiernie utrudnione, żądać unieważnienia umowy. Skutkiem wyzysku nie jest więc nieważność zawartej umowy, lecz umożliwienie sądowi, na żądanie pokrzywdzonego, ukształtowania zobowiązania o równoważnych świadczeniach. Dopiero gdy tego osiągnąć nie można, konieczne staje się unieważnienie umowy.

Ponieważ polskie prawo nie zabrania zawierania umów niekorzystnych, rażąca dysproporcja świadczeń nie jest wystarczająca do zakwalifikowania konkretnego przypadku jako lichwy. Zgodnie z art. 388 k.c. muszą zaistnieć dodatkowe przesłanki w postaci: przymusowego położenia, niedołęstwa lub niedoświadczenia drugiej strony.

Dopełnieniem uregulowań Kodeksu cywilnego jest art. 304 Kodeksu karnego z dnia 6 czerwca 1997 r. (Dz.U. 2018, poz. 1600 t.j.), który stanowi o przestępstwie lichwy 
w następujący sposób: „Kto, wyzyskując przymusowe położenie innej osoby fizycznej, prawnej albo jednostki organizacyjnej niemającej osobowości prawnej, zawiera z nią umowę, nakładając na nią obowiązek świadczenia niewspółmiernego ze świadczeniem wzajemnym, podlega karze pozbawienia wolności do lat 3”. Przestępstwo określone w art. 304 jest przestępstwem publicznoskargowym, ściganym z urzędu. W art. 304 chodzi o umowę krzywdzącą. Warunkiem uznania nadmiernych korzyści jako karalnej lichwy jest jednak wykorzystanie przymusowego położenia drugiej strony bez względu na to, czy sytuacja ta była zawiniona, czy nie. Omawiane przestępstwo można popełnić tylko umyślnie. Aktualne ujęcie art. 304 k.k. nakłada więc na organy wymiaru sprawiedliwości obowiązek wnikliwego analizowania zawartych umów, z uwzględnieniem także i tego, że nie każda umowa o zwiększonym ryzyku gospodarczym i przewidująca dla jednej ze stron wyższe korzyści oznacza a priori, iż mamy do czynienia z karalnym wyzyskiem jednej ze stron.

Przesłanką lichwy jest rażąca dysproporcja świadczeń. Umowy dotknięte wyzyskiem cechuje wykorzystanie bez skrupułów przymusowej sytuacji lub niewiedzy dłużnika. Przy ocenie sąd kieruje się m.in. warunkami rynkowymi, rozkładem ryzyka, obowiązującym zwyczajem, charakterem usługi (spekulacyjny lub niespekulacyjny) i pakietowym charakterem oferty. Naruszenie ekwiwalentności musi mieć charakter znaczny, oczywisty i rzucający się w oczy.

Przepisy o odsetkach maksymalnych oraz regulujące maksymalną wysokość pozaodsetkowych kosztów kredytu tworzą system cywilnoprawnej ochrony przed lichwą. $\mathrm{Na}$ wprowadzenie ustawowych regulacji wpłynęły stosunkowo łatwy dostęp do rynku kredytowo-pożyczkowego oraz bardzo dynamiczny wzrost tego rynku w ostatnim okresie, a także wysoki stopień zróżnicowania ofert, skomplikowany charakter umów kredytowych oraz niski poziom wiedzy finansowej kredytobiorców.

Udzielając kredytu konsumenckiego, podmioty finansowe pobierają należne sobie wynagrodzenie za udostępnienie kapitału oraz za usługi świadczone w trakcie procesu kredytowego. Na całkowity koszt kredytu konsumenckiego składają się odsetki oraz prowizje i opłaty. Wchodzą one w skład odsetkowych (odsetki) i pozaodsetkowych (prowizje i opłaty) kosztów kredytu.

Wysokość odsetek i pozostałych składników kosztów kształtowana jest przez przepisy prawa i rynek. Z jednej strony przez ustawodawcę, który nakłada na instytucje finansowe limity wysokości opłat, a z drugiej strony przez koszty działalności instytucji finansowej, popyt ze strony kredytobiorców i konkurencję (Dobosiewicz, 2007: 51). Argumentem za normatywnym uregulowaniem maksymalnej wysokości odsetek jest ograniczenie w stosunkach cywilnoprawnych odsetek znacznej wysokości (Wałega, 2013: 57).

Ustawa z 7 lipca 2005 r. zmieniająca k.c. oraz niektóre inne ustawy (Dz.U. 2005 nr 157, poz. 1313) wprowadziła od 20 lutego 2006 r. limit odsetek maksymalnych. Zgodnie z nią w art. 359 k.c. dodano $\$ 21 \mathrm{w}$ brzmieniu „maksymalna wysokość odsetek nie może przekraczać czterokrotności wysokości stopy kredytu lombardowego Narodowego Banku Polskiego". Ponadto wprowadzono zmiany w ustawie o kredycie konsumenckim z $2001 \mathrm{r}$. dotyczące tego, iż łączna kwota opłat, prowizji i kosztów związanych z zawarciem umowy kredytu konsumenckiego nie może przekraczać 5\% kwoty udzielonego kredytu, z wyłączeniem kosztów jego zabezpieczenia w tym ubezpieczenia.

Nowa ustawa o kredycie konsumenckim z 12 maja 2011 r. utrzymała zasady dotyczące odsetek maksymalnych, ale zniosła ograniczenie dotyczące pozaodsetkowych kosztów kredytu. 
W wyniku nowelizacji k.c. od 1 stycznia 2016 r. obowiązuje nowy wzorzec ustalania odsetek maksymalnych, oparty na stopie referencyjnej, a nie na stopie lombardowej. Reguluje go art. $358 \$ 2$ k.c., zgodnie z którym, jeżeli wysokość odsetek nie została w inny sposób określona, należą się odsetki ustawowe w wysokości równej sumie stopy referencyjnej Narodowego Banku Polskiego i 3,5 punktów procentowych. Odsetki maksymalne wynikające z czynności prawnej - odnoszące się również do maksymalnego oprocentowania kredytu - nie mogą w stosunku rocznym przekraczać dwukrotności wysokości odsetek ustawowych (Wiśniewski, 2018). Według stanu z sierpnia 2018 r., odsetki nie mogą przekroczyć $10 \%$ w skali roku. W sytuacji gdy odsetki wynikające z czynności prawnej przekroczą wysokość odsetek maksymalnych, należą się tylko odsetki maksymalne. Ponadto zastrzeżono, że postanowienia umowne nie mogą ograniczyć lub wyłączyć przepisów o odsetkach maksymalnych.

Zmiany w Kodeksie cywilnym objęły również odsetki za opóźnienie. Wysokość odsetek z tytułu opóźnienia może być określona w umowie lub wynikać z ustawy. W przypadku, gdy odsetki nie zostały oznaczone w umowie, za każde opóźnienie w spłacie należą się odsetki ustawowe w wysokości równej sumie stopy referencyjnej NBP i 5,5 punktów procentowych. Odsetki maksymalne za opóźnienie nie mogą przekraczać dwukrotności wysokości odsetek ustawowych za opóźnienie w stosunku rocznym (wg stanu z sierpnia 2018 r. jest to $14 \%$ w skali roku).

Pozaodsetkowe koszty kredytu to wszystkie koszty, które ponosi konsument w związku z umową o kredyt konsumencki, z wyłączeniem odsetek (Czech, 2018). Obejmują one zarówno koszty ponoszone jednorazowo, jak i koszty, których wysokość jest uzależniona od okresu kredytowania (Stanisławska, 2018). Do pozaodsetkowych kosztów, wchodzących w skład całkowitego kosztu kredytu, należą prowizja i pozostałe opłaty. Banki pobierają różnego rodzaju opłaty zarówno przed, jak i po zaciągnięciu kredytu, np. za rozpatrzenie wniosku kredytowego, przygotowanie oferty, przedterminową spłatę kredytu, przewalutowanie kredytu, zmianę wysokości płaconych rat. Opłaty pozaodsetkowe są ustalane kwotowo lub procentowo i pełnią funkcję kompensacyjną (odszkodowawczą) (Rogoń, 2018).

Prowizja jest głównym pozaodsetkowym kosztem kredytu. Pobierana jest za czynności związane z udzielaniem kredytu. Ma zupełnie inny charakter niż odsetki, które są pobierane za udostępnienie kapitału. Celem prowizji jest zrekompensowanie wydatków, które ponosi kredytodawca za doprowadzenie do zawiązania umowy kredytu, np. kosztów związanych ze sprawdzeniem historii kredytowej klienta w rejestrach dłużników. Prowizja może być pobierana z góry, w formie jednorazowej opłaty, ale również może być skredytowana i rozłożona na raty. Doliczanie opłat pozadosetkowych do kwoty kredytu podnosi całkowity koszt kredytu, ponieważ zwiększa wysokość płaconych odsetek.

Ochronę kredytobiorców przed nadmiernymi kosztami pozadosetkowymi przywrócono w 2016 r. Ustawa z dnia 5 sierpnia 2015 r. o zmianie ustawy o nadzorze nad rynkiem finansowym oraz niektórych innych ustaw (Dz.U. 2015, poz. 1357). Maksymalną wysokość pozaodsetkowych kosztów w całym okresie kredytowania oblicza się według następującego wzoru:

$$
M P K K \leq(K * 25 \%)+\left(K * \frac{n}{R} * 30 \%\right),
$$


gdzie

MPKK - maksymalna wysokość pozaodsetkowych kosztów kredytu,

K - całkowita kwota kredytu,

$\mathrm{n}$ - okres spłaty wyrażony w dniach,

$\mathrm{R}$ - liczba dni w roku.

Podstawą do obliczenia maksymalnej wysokości pozaodsetkowych kosztów kredytu jest całkowita kwota kredytu, która zgodnie z art. 5 (7) Ustawy z dnia 12 maja 2011 r. o kredycie konsumenckim oznacza „maksymalną kwotę wszystkich środków pieniężnych nieobejmujących kredytowanych kosztów kredytu, które kredytodawca udostępnia konsumentowi na podstawie umowy o kredyt, a w przypadku umów, dla których nie przewidziano tej maksymalnej kwoty, suma wszystkich środków pieniężnych nieobejmujących kredytowanych kosztów kredytu, które kredytodawca udostępnia konsumentowi na podstawie umowy o kredyt" (Dz.U. 2018, poz. 933 t.j.).

Ustawa stanowi, że:

- pozaodsetkowe koszty nie mogą przekroczyć 25\% kwoty kredytu i 30\% za każdy rok trwania umowy,

- wszystkie koszty pozaodsetkowe nie mogą przekroczyć równowartości wypłaconej kredytobiorcy kwoty,

- przy udzieleniu kolejnego kredytu w okresie do 120 dni od udzielenia pierwszego finansowania limit kosztów pozaodsetkowych odnosi się do pierwszej umowy (Osajada, 2018).

Ustawa nakłada także limit na wysokość kosztów pozaodsetkowych za opóźnienie, które wraz z odsetkami za opóźnienie nie mogą przekroczyć odsetek maksymalnych za opóźnienie.

\section{Wpływ regulacji antylichwiarskich na rynek}

Pojawienie się regulacji o charakterze cen maksymalnych uruchomiło typowe, znane już wcześniej w innych krajach lub na innych rynkach, procesy dostosowawcze. Dotknęło przede wszystkim podmioty finansowe $\mathrm{z}$ sektora pozabankowego (przedsiębiorstwa pożyczkowe), które specjalizują się w udzielaniu pożyczek na mniejsze kwoty. Nowe prawo, mimo szerokiej definicji kosztów pozaodsetkowych, nie okazało się szczelne (Kisiel, 2018). Część podmiotów omija przepisy dotyczące limitów kosztów pozaodsetkowych za pomocą refinansowania zobowiązań. Praktyka ta polega na przenoszeniu konsumenta do innego pożyczkodawcy, który spłaca „stare” zadłużenie i udziela finansowania na podstawie nowej umowy (z limitem kosztów liczonym od nowa). Niektórzy pożyczkodawcy gwarantują nawet klientom „rolowanie” zadłużenia przez przeniesienie kosztu wydłużonej spłaty do innej umowy, pozornie niezależnej od pierwotnej pożyczki. Ograniczenia ustawowe omijane są także przez stosowanie innych umów aniżeli umowa kredytu, które nie podlegają przepisom regulującym kredyt konsumencki (np. sprzedaż z przyrzeczeniem odkupu, o doradztwo lub pośrednictwo w zorganizowaniu finansowania, o przechowanie rzeczy, wycenę rzeczy).

Limity ustawowe wyeliminowały z rynku kredyty konsumenckie na bardzo krótki okres i bardzo małe kwoty, które przy niskiej cenie kredytu stały się dla kredytodawców nieopłacalne. Przepisy przyczyniły się do zwiększenia kwot kredytu i wydłużenia okresu kredytowania. Zmiany w tym kierunku potwierdzają dane, iż w 2017 r. średnia wartość 
udzielonej pożyczki wzrosła aż do 2122 zł, znacznie przewyższając średnią z roku 2016, która wynosiła 1626 zł (Wyższe..., 2018). Średnia wartość udzielonej pożyczki po raz pierwszy w historii przekroczyła 2000 zł i jednocześnie o około 1/5 zmniejszyła się liczba pożyczkobiorców. Wydłużeniu uległ również okres kredytowania. Pożyczki udzielane na okres od 1 roku do 2 lat wysunęły się na pierwsze miejsce i zdominowały rynek pożyczek pozabankowych w 2017 r. Oznacza to zmarginalizowanie typowych chwilówek. Zwiększenie kwot kredytu i wydłużenie okresu kredytowania wpływa na wzrost zadłużenia gospodarstw domowych, a co za tym idzie - zwiększa ryzyko utraty zdolności spłaty kredytu.

Negatywny wpływ cen maksymalnych osłabił relatywnie wysoki poziom limitów, który wpłynął na zmniejszenie rozmiarów nierównowagi rynkowej. Wpływ na wzrost kwot udzielanych kredytów miały także wzrost zdolności kredytowej z tytułu transferów socjalnych (Opolski, Gemzik-Salwach, 2016) oraz ulepszenie metod oceny zdolności kredytowej klientów. Wcześniej obniżanie kwoty pożyczki były najczęstszym narzędziem ograniczania ryzyka udzielenia pożyczek osobom o niepewnej sytuacji finansowej. Obecnie przedsiębiorstwa pożyczkowe stosują systemy scoringowe, niemal tak dokładne jak w bankach, dzięki czemu mogą dokładnie określać zdolność kredytową swoich klientów

Limitowanie odsetek ograniczyło dostęp społeczeństwa do kredytu, ponieważ wyeliminowało z rynku produkty na niskie kwoty i krótki okres. Tym samym wyeliminowało z rynku kredyty droższe ze względu na wysoką szkodowość, adresowane do kredytobiorców o wysokim ryzyku. Ostatecznie regulacja zepchnęła tego typu klientów do szarej strefy, w której pozbawieni są praw konsumenckich. Ograniczenie dostępu do kredytu jest formą wykluczenia finansowego. Ma ono szczególnie dotkliwy charakter w dobie upowszechnienia (demokratyzacji) kredytu (Lewicka-Strzałecka, 2010: 216-218).

Ochrona konsumentów oparta na limitowaniu opłat jest przestarzała i nieskuteczna. W krajach zachodnich albo nie ma limitów ustawowych, albo są one znoszone (Szpringer, 2014: 240). Na przykład w Niemczech ochrona konsumentów ma przede wszystkim charakter sądowy i oparta jest na klauzulach generalnych (zgodności z dobrymi obyczajami). Z kolei we Francji nie ma kwotowo określonej górnej granicy opłat, natomiast za lichwiarskie uznawane są odsetki, które przewyższają o 1/3 średni poziom dla pożyczek danego typu w poprzednim kwartale. Doświadczenia Niemiec i Francji pokazują, że z nielegalnych pożyczek korzysta tam dwa razy więcej klientów aniżeli w krajach, w których takich ograniczeń nie ma (Wielka Brytania) (Szpringer, 2009: 216). Nietrafne regulacje zamiast chronić najsłabszych, obracają się przeciwko nim (Szpringer, 2010: 56). W krajach wysokorozwiniętych nacisk kładzie się na odpowiedzialne kredytowanie, oparte na rzetelnej ocenie zdolności kredytowej. Ważne jest ujawnianie informacji i indywidualizacja oferty przez profilowanie klientów i dostarczanie produktów dostosowanych do ich potrzeb.

Limitowanie wysokości cen (opłat) jest uzasadniane ochroną kredytobiorców przed wyzyskiem. Pogląd o istnieniu wyzysku formułowany jest często na podstawie informacji o rzeczywistej rocznej stopy oprocentowania (RRSO). Rzeczywista roczna stopa oprocentowania określa całkowity koszt kredytu ponoszony przez konsumenta, wyrażony jako wartość procentowa całkowitej kwoty kredytu w stosunku rocznym. Wskaźnik RRSO zarówno przed wprowadzeniem limitów, jak i po, przy kredytach na krótki okres, przyjmuje bardzo duże wartości. Wynika to z zasad jego konstrukcji. Skłania to niekiedy do formułowania chybionych postulatów dalszego limitowania opłat w celu skutecznego obniżenia RRSO. 
RRSO traktuje się mylnie jako rzeczywisty koszt kredytu, który poniesie kredytobiorca. Może on odzwierciedlać rzeczywistą cenę kredytu tylko w pewnych warunkach. Pozwala prognozować rzeczywisty koszt kredytu dla kredytów długoterminowych (trwających ponad rok), a nie krótkoterminowych (tygodniowych czy miesięcznych) (Nowak, 2017: 285-286). RRSO ma charakter czysto informacyjny i porównawczy. Ma za zadanie pełnić funkcję jednolitego i powszechnego kryterium, które mimo różnic w konstrukcji ofert kredytowych pozwoli kredytobiorcom wskazać kredyt najtańszy przed zawarciem umowy.

Wprowadzenie obowiązku podawania informacji na temat RRSO przez kredytodawców nie rozwiązuje problemu niewiedzy dotyczącej całkowitych kosztów kredytu w chwili zawierania umowy. W momencie zaciągania kredytu kredytobiorca nie wie, jaki będzie rzeczywisty całkowity koszt kredytu - wiedzę tę będzie posiadał dopiero po zamknięciu kredytu (Golec, 2016: 218). Całkowity koszt kredytu zależy bowiem od zdarzeń, które nastąpią w okresie spłaty kredytu (np. zmiany wysokości stóp procentowych, skrócenia lub wydłużenia okresu spłaty kredytu). Kredytobiorca może oczywiście, a nawet powinien, podjąć działania zmierzające do obniżenia kosztu kredytu, ale nie jest w stanie wyeliminować niepewności dotyczących rzeczywistego kosztu kredytu. Do instrumentów służących obniżeniu kosztu kredytu, pozostających w gestii kredytobiorcy, należą przede wszystkim obniżenie kwoty kredytu i skrócenie okresu kredytowania.

Należy pamiętać ponadto, że w kredytach na krótki okres cena kredytu nie jest najważniejsza dla kredytobiorcy i to nie od jej wysokości zależy decyzja kredytowa. Liczą się przede wszystkim minimum formalności, które trzeba spełnić, i to, jak szybko kredyt zostanie wypłacony.

Informacja na temat RRSO nie chroni przed nadmiernym zadłużeniem ani nie obniża ryzyka utraty zdolności spłaty kredytu. Na wysokość RRSO nie wpływa wysokość kwoty kredytu ani rodzaj tytułów składników płatności.

\section{Zakończenie}

Doświadczenia historyczne, ale też te zupełnie współczesne pokazują, że walka z lichwą przez narzucanie maksymalnej ceny kapitału jest nieskuteczna i wywołuje niepożądane konsekwencje. Bardziej jednoznaczny wpływ na obniżenie kosztów kredytu aniżeli limitowanie opłat kredytowych, mają stabilizacja sytuacji gospodarczej, nasycenie rynku kapitałem i rozwój konkurencji (wzrost podaży). Limitowanie opłat prowadzi do wycofania z rynku kredytów na krótki okres i małe kwoty, których nie opłaca się udzielać. Wpycha tym samym najsłabszych kredytobiorców do sektora pożyczek prywatnych, w którym prawo konsumenckie nie obowiązuje i bezpieczeństwo transakcji jest niskie. Wywołuje presję na zwiększanie kwot kredytów i wydłużanie okresu kredytowania, a tym samym przyczynia się do wzrostu zadłużenia gospodarstw domowych. Zapewne z tych powodów rząd wycofał się z zapowiadanej w końcu 2016 r. kolejnej ustawy antylichwiarskiej, która miała na celu dalszą redukcję opłat pozaodsetkowych.

Limitowanie wysokości opłat nie ogranicza nieodpowiedzialnego kredytowania, tzn. pożyczania tym, którym nie powinno się pożyczać. Kluczem do odpowiedzialnego kredytowania jest właściwa ocena zdolności kredytowej, uwzględniająca rzeczywistą sytuację finansową kredytobiorcy. Ocena zdolności kredytowej będzie przeprowadzona zgodnie z najlepiej pojętym interesem klienta wtedy, gdy brak spłaty kredytu będzie zagrażać 
interesom kredytodawcy. W każdym innym przypadku kredytodawca nie będzie przywiązywał odpowiedniej wagi do sytuacji kredytobiorcy i będzie obciążał stratami z pojedynczej umowy pozostałych klientów.

\section{Literatura}

References

Alqahtani, F., Mayes, D.G., (2018, 30 października). The Impact of the Global Financial Crisis on Islamic Banking. Pozyskano z: https://www.researchgate.net/publication/298355699_The_Impact_of_ the_Global_Financial_Crisis_on_Islamic_Banking

Arystoteles, (1953). Polityka. Wrocław: Ossolineum.

Bączyk, M. (2007). Komentarz do art. 110 ustawy - Prawo bankowe. W: E. Fojcik-Mastalska (red.), Prawo bankowe. Komentarz. Warszawa: LexisNexis.

Bień, A., Bień, W. (2009). Kalkulacja ceny pieniadza. Warszawa: Difin.

Czech, T. (2018). Kredyt konsumencki. Komentarz. Warszawa: Wolters Kluwer Polska.

Dobosiewicz, Z. (2007). Kredyty i gwarancje bankowe. Warszawa: PWE.

Galbraith, J.K. (1991). Ekonomia w perspektywie (krytyka historyczna). Warszawa: PWN.

Golec, M.M. (2016). Instytucje i ustugi bankowe. Poznań: Wydawnictwo Szkoły Bankowej w Poznaniu.

Gostomski, E. (2018, 10 października). Kultura bez lichwy. Pozyskano z: https://www.bankier.pl/wiadomosc/Kultura-bez-lichwy-2053998.html.

InfoDług: Indeks Zaległych Płatności Polaków - sierpień 2018. (2018, 15 października). Pozyskano z: https://media.bik.pl/publikacje/read/400554/infodlug-indeks-zaleglych-platnosci-polakow-sierpien-2018

Kisiel, M. (2018, 25 października). „Antylichwa 2.0” ma już 2 lata, a prawo wciq்̨̇ dziurawe. Pozyskano z: https://www.bankier.pl/wiadomosc/Antylichwa-2-0-ma-juz-dwa-lata-a-prawo-wciazdziurawe-7576474.html

Korzeb, Z. (2017). Lichwa - fikcja czy rzeczywistość. Bezpieczny Bank, 2(67), 127-142.

Krajewski, A. (2018, 10 października). Jak ominać Boga, czyli lichwa, pożyczki i banki według wielkich religii. Pozyskano z: http://biznes.gazetaprawna.pl/artykuly/766685,jak-ominac-boga-czyli-lichwa-pozyczki-i-banki-wedlug-wielkich-religii.html

Kultura bez lichwy. (2018, 30 października). Pozyskano z: https://finanse.wp.pl/kultura-bez-lichwy$-6114524961806465 \mathrm{a}$

Lewicka-Strzałecka, A. (2010). Etyczne aspekty instytucji kredytu. Annales. Etyka w życiu gospodarczym, 13(1), 213-221.

Nowak, P. (2017). Bezpieczeństwo konsumenta w transakcjach kredytowych. Przedsiębiorczość Edukacja, 13, 275-288.

Opolski, K., Gemzik-Salwach, A. (2016). Perspektywy finansowe i wiarygodność kredytowa gospodarstw domowych w kontekście programu „Rodzina 500+” (Propozycja metody kalkulacji finansowej na przykładzie województwa podkarpackiego). Bezpieczny Bank, 2(63), 90-118.

Osajda, K. (2018). Art. 36 - Ustawa o kredycie konsumenckim. W: K. Osajda (red.), Ustawa o kredycie konsumenckim. Komentarz. Warszawa: C.H. BECK.

Ratajczak, M. (2012). Finansyzacja gospodarki. Ekonomista, 3, 281-301.

Rogoń, D. (2005). Komentarz do art. 110 ustawy - Prawo bankowe. W: F. Zoll (red.), Prawo bankowe. Komentarz. Tom I i II, Katowice: Zakamycze.

Stanisławska, M. (2018). Art. 36a - Ustawa o kredycie konsumenckim. W: M. Stanisławska (red.), Ustawa o kredycie konsumenckim. Komentarz. Warszawa: C.H. BECK.

Szpringer, W. (2010). Regulacja konkurencji a konkurencja regulacyjna. Warszawa: Wydawnictwo Poltex.

Szpringer, W. (2009). Społeczna odpowiedzialność banków. Między ochroną konsumenta a ochrona socjalna. Warszawa: Wolters Kluwer Polska. 
Szpringer, W. (2014). Instytucje nadzoru w sektorze finansowym. Kierunki rozwoju. Warszawa: Wydawnictwo Poltext.

Thurow, L., Heilbroner, R.L. (2006). Ekonomia od podstaw, Gliwice: Wydawnictwo Helion.

Wałęga, G. (2013). Kredytowanie gospodarstw domowych. Warszawa: PWE.

Wiśniewski, T. (2018). Komentarz do art. 359 Kodeksu cywilnego. W: J. Gudowski (red.), Kodeks cywilny. Komentarz. Tom III. Zobowiązania - część ogólna. Warszawa: Wolters Kluwer Polska.

Wyższe kwoty pożyczek, ale mniej klientów, czyli aktualna sytuacja na rynku chwilówek. (2018, 30 października). Pozyskano z: https://pozyczasz.pl/aktualnosci/wyzsze-kwoty-pozyczek-ale-mniej-klientow-czyli-aktualna-sytuacja-na-rynku-chwilowek

Paweł Nowak, dr, ekonomista, adiunkt w Katedrze Ekonomii i Polityki Gospodarczej na Wydziale Politologii Uniwersytetu Pedagogicznego im. KEN w Krakowie. Zainteresowania naukowe: mikroi makroekonomia, bezpieczeństwo obrotu gospodarczego, ochrona konsumenta. Autor publikacji naukowych z zakresu ekonomii, prawa i finansów.

Pawel Nowak, PhD, economist and assistant professor in the Department of Economics and Economic Policy at the Faculty of Political Sciences of the Pedagogical University of Cracow. Main research interests: economy, safety of transaction and consumer protection. He is the author of numerous articles on economics, law and finance.

ORCID: 0000-0002-8160-242X

\section{Adres/Address:}

Uniwersytet Pedagogiczny im. Komisji Edukacji Narodowej

Wydział Politologii

Katedra Ekonomii i Polityki Gospodarczej

ul. Podchorążych 2

30-084 Kraków, Polska

e-mail: pawel.nowak@up.krakow.pl 